
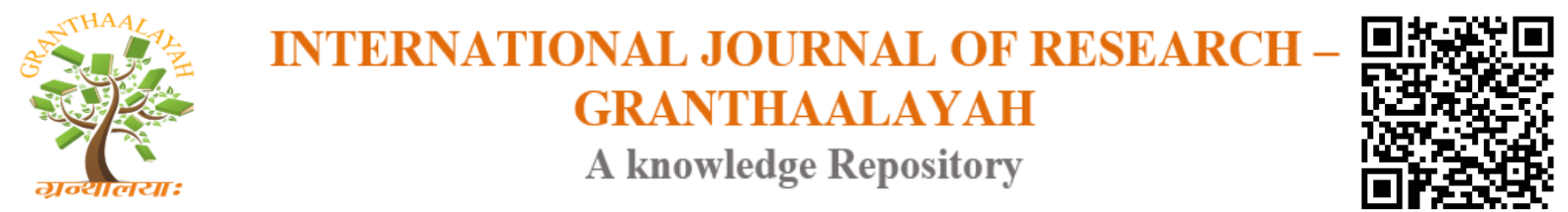

Science

\title{
AYURVEDIC REVIEW OF DIABETES MELLITUS (PRAMEHA)
}

\author{
Dr.Tushar Ravindra Karnawat ${ }^{* 1}$, Dr. P. C. Yavatkar ${ }^{* 2}$ \\ ${ }^{* 1}$ (M.D. Scholar), Kayachikitsa, Svnht's Ayurvedic Mahavidyalaya Rahuri Factory, India \\ ${ }^{* 1}$ Prof. and H.O.D, kayachikitsa Department, Svnht's Ayurvedic Mahavidyalaya Rahuri Factory, \\ India
}

\begin{abstract}
India is set to emerge as the diabetic capital of the world and it is very shameful prediction which India has to face. Heredity, Sedentary life style, lack of exercise and yoga, stress, and improper diet habits are main reasons for spreading of the diabetes. In order to prevent the primary onset we need to concentrate on the next generation of existing diabetes patients. Making them aware will be the first task, followed by provocation for action, followed by action in reality.

As diabetes is metabolic disorder it cannot be treated merely by controlling blood sugar level. Ayurveda aimed at rejuvenating the body for not only controlling blood sugar level but also ensure that no further complication should be caused. Ayurvedic treatment for diabetes based on entire change in life style of the person, along with proper medication and diet patient is advised to lead healthy and active life.
\end{abstract}

Keywords: Diabetes; Prameha; Ayurveda; Control; India.

Cite This Article: Dr.Tushar Ravindra Karnawat, and Dr. P. C. Yavatkar. (2017). "AYURVEDIC REVIEW OF DIABETES MELLITUS (PRAMEHA)." International Journal of Research - Granthaalayah, 5(8), 217-222. 10.29121/granthaalayah.v5.i8.2017.2216.

\section{Introduction}

Ayurveda is an ancient medical science which is based on scientific principles, described diabetes under the name of Prameha or Madhumeha.

According to WHO diabetes mellitus is a metabolic disorder of multiple etiology which is characterised by chronic hyperglycemia with disturbance of carbohydrate, fat, and protein metabolism resulting from defects of insulin secretion, insulin action or both.

Now with the change in concepts of health and disease attention has been drawn to Ayurveda once again. Today we can compare prameha or madhumeha with diabetes mellitus. Ancient text describes 20 types of prameha, out of these 10 are due to kapha (early stage), 6 are due to pitta (acute stage), 4 are due to vata (chronic stage). Diabetes is considered as major disease because if not treated in time, it can lead to several complications like diabetic neuropathy, diabetic 
retinopathy, kidney disorders like acute or chronic kidney failure, urological problems and many more. Ayurvedic treatment and proper ahar-vihara can help us to avoid these kinds of complications and offer to live along as well as healthy life for society.

\section{Materials and Methods}

For the present review detailed literary study performed. The detailed content and references are analysed from available text. Principle texts referred are charaka, sushruta, vagbhata, and other samhita. Some other ayurvedic books also referred. Relevant references are taken from other modern books.

HETU (causative factors of prameha) (3)

1) It manifest due to two main etiological factors. First is Sahaja( heriditory/ congenital) due to morbidity of shukra and shonita and seconed one is Apathyanimittaj due to improper dietetics and activities.

2) Sedentery life style, excessive sleeping during day time, having meat soup of domestic or aquatic animals, milk products, jaggerry etc.

3) Preperation of all other kapha promoting substance, laziness, intake of food which are cold, unctus, fatty, and sweet food.

4) food, drinks, and activities which aggrevates meda, mutra, kapha are main etiological factors for genesis of prameha.

5) All etiological factors mentioned in the santarpanottha vikara are responsible for prameha.

SAMPRAPTI (Pathogenesis): $(1,3,4)$

Improper processed vata, pitta, and kapha mixex with dushyas like meda, rakta, shukra, ambu, vasa, lasika, majja, rasa, ojas and mamsa in mutravaha strotasa leads to manifestation of 20 types of prameha. Increase or decrease of proportion in combination of doshas, dhatus, mala and ahara are main factors responsible for development of various types of prameha.

PURVARUPA (premonitory symptoms): $(3,4,8,10)$

Aggrivated all three doshas develop following characteristic in prediabetic stage.

1) Malin danta (Excess accumulation of waste over teeth)

2) Hastapad daha(burning sensation in hands and feet)

3) Mukhamadhurya (sweetishness in oral cavity)

4) Sweda (excessive swetting )

5) Shithilangata( flaccidity of body)

6) Excessive growth of hair, nails etc

7) Matting of hair

8) Trishna (thirst)

9) Fleshy smell from body

10) Adherence of excreta in body orifices

11) Accumulation of bees and ants over the body and urine

RUPA (Symptoms)

1) Increase in quantity of urine along with premonitory symptoms 
2) Prabhoot mutrata (polyuria)

3) Avilmutrata(turbid urine)

4) All medodushti lakshna

Though dosha and dushya's are same, thre combination being different, leads to differences in colour, odur and touch of urine based on these, different types of pramehas classified.

CLASSIFICATION AND ITS SADHY ASADHYATVA: $(1,2,3,9)$

A) ACCORDING TO AIETIOLOGY

1) Sahaj (hereditary or chromosomal defects from parents)- Asadhya

2) Apathyanimittaja (improper dietetics and activities) - Yapya

B) ACCORDING TO PHYSICAL MANAGEMENT

1) Apatarpanjanya- karshyaprameha- (lean diabetic) -Yapya

2) Santarpanjanya-sthula prameha-( obese dietetic) -Sadhya

C) ACCORDING TO DOSHA

I. KAPHAJ PRAMEHA: -further divided into 10 types

1) Udak meha

2) Ikshuvalikarasa meha

3) Sandrameha

4) Sandraprasad meha

5) Shukla meha

6) Sita meha

7) Shukra meha

8) Sikata meha

9) Shanair meha

10) Alala meha

All above ten prameha are Sadhya (curable) due to compatibility in principles of treatment.

II. PITTAJ PRAMEHA: develops in 6 types of prameha

1) Ksharmeha

2) Nilameha

3) Manjishtha Meha

4) Kala Meha

5) Rakta Meha

6) Haridra Meha

All pittaj pramehas are Yapya(manageable) due to incompatibilities in line of treatment.

III. VATAJ PRAMEHA: divided into 4 types

1) Vasa Meha

2) Majja Meha

3) Hastimeha

4) Lasikameha

Vataj prameha is Asadhya (incurable) not only due to variety and antagonisity in the line of treatment but also severity in the complications. 
UPADRAVA OF PRAMEHA (complications): (3)

Thirst, diarrhoea, fever, weakness, anorexia and indigestion, development of prameha pidakas and putrification of muscle tissue leads to alaji and vidhradhi in chronic stage of prameha.

CHIKITSA SUTRA (treatment) $(5,6,7,10)$

Prameha can be classified in two categories i.e. sthulaprameha and karshya prameha, patient belonging sthuka prameha should be administered by shodhana(eliminating) therapy and patient belonging karshyaprameha should be given santarpana and sanshamana (nourishing) therapy.

Considering the haman on of the disease, after shodhana chikitsa patient should be given santarpana or refreshing therapy, because apatarpana in this condition may produce gulma, mehanbasti shula (pain in bladder and phallus), mutragraha (retention of urine), such patient shold be given santarpana depending upon digestive power of that person.

\section{PANCHAKARMA IN PRAMEHA}

Bio purifactory methods include vamana (emesis) and langhana (fasting) therapies administered at proper time, cure kaphaja prameha.

Pittaj types of prameha are overcome by virechana (haman on), santarpana (refreshing therapy) and haman chikitsa.

Patient who is not suitable for shodhana chikitsa should be given alleviation i.e. haman chikitsa.

\section{PATHYA (UPASHAYA)}

AHARA:

1) Patient should eat roasted meat of animals and birds and various preparations of barley.

2) Cooked barley without adding any unctus articles, saktu (roasted corn flour) mixed with meat soup.

3) Barley soaked in decoction of triphala and mixed with honey should be consumed. It acts as a tarpana and helps to overcome the disease.

4) Cooked shashtika rice mixed with the soup of truna dhanyas, vedtables of bitter and astringent taste, groups of vegetables and oil of danti, ingudi, atasi, and sarshapa.

5) The following eatables are helpful in case of prameha: soft bamboos, wild variety of kulattha, old wheat grains, shali rice, yusha of pulses of kulattha, mudga and pigeon pea, vatyamanda (manda prepared by cooking barley in water measuring four times), buttermilk, palm fruit, fresh banana fruit, jambu, garlic pearls, kharjura etc.

6) Food stuff like mantha, sour juice, powder made with meat soup of vishkira (one having habit of eating waste products) and pratuda (one having log beaks) as well as wild animals is considered as a good diet.

\section{VIHARA}

1) During advance stage of disease patient should indulge in all kind of exercises regularly, sports, wrestling, sports, riding elephant and horses, archery etc.

2) diabetic patient should undertake 100 yojana journey on foot without using footwear and umbrella. 
3) Patient should stay in the company of animals, consume their urine and dund and move along with them always.

4) Purification of body through bitter herbs like neem and haridra should be applied to the patient.

5) Once the symptoms of prameha disease are clear one should first have langhana (fasting), vamana (emesis) and virechana (purgation).

\section{APATHYA (ANUPASHAYA)}

1) Avoid suppression of urine urge,

2) Smoking,

3) Fomentation and blood letting

4) Remaining seated by the side of soft cushion,

5) Sleeping during day time

6) Patient should not take fresh cereals, large amount of curd, sugarcain juice, contaminated water, meat of aquatic animals.

\section{COMMON REMEDIES USED IN PRAMEHA $(10,12)$}

1) Nyagrodhadi churna- $3 \mathrm{gm}$ with honey

2) Eladi churna- 1gm twice a day with tandulodaka

3) Mustadi kwatha -30 to $50 \mathrm{ml}$ with water

4) Vidangadi kwath -30 to $50 \mathrm{ml}$ with honey

5) Chandrakala gutika-250 to $500 \mathrm{mg}$ with water

6) Chandraprabha vati- $500 \mathrm{mg}$ to $1 \mathrm{gm}$ with water

7) Shalmali grhuta-15 to $30 \mathrm{ml}$ of grhuta with lukewarm water

8) Dadimadi ghruta-6 to 12 gm of ghruta with lukewarm water

9) Vaidangadi lauha - 250 to $500 \mathrm{mg}$ with lukewarm water

10) Devtarvyarishta - 12 to $25 \mathrm{ml}$ with equal water

\section{Conclusion}

Diabetes is a slow killer with no curable treatment. In today's era people with diabetes have to face further complications like blindness, kidney failure and cardiac disorders. However proper medications, awareness and practicing daily exercise can reduces the severity of the disease. The goal of this article is to give general information about prameha explained in the ancient text.

\section{References}

[1] Madhav nidan; translated into English by Dr. K.R. Srikantha murthy; chaukhmba publication, Varanasi, krishnadas academy, chapter no 33; page no 116,119.

[2] Sharangdhar samhita translated into English by Dr. K.R. Shrikantha murthy; chaukhamba publication, Varanasi.( pratham khanda pratham khanda chapter no 7; Madhyam khanda chapter no 2;page no 12.

[3] Ashtanga hridayam, nidansthan translated into English by Dr.K.R. Shrikantha murthy , chaukhamba publication, Varanasi, chapter 10 page no 92-99.

[4] Yogratnakar- pramehprakarnam, by Dr.Indeqdev Tripathi and Dr. Dayashankar tripathy, chaukhamba academy, Varanasi, chapter prameha nidana; page no- 622 to 641. 
[5] Charak chikitsa sthan; by agnivesham, translated into English by dr.ram karan and vd. Bhagwan das, chaukhamba Sanskrit series, Varanasi, 2001.

[6] Sushrut samhita;by kaviraj bhashgraha; chaukhamba series, Varanasi; volume 2, chapter 13; page no. 286-391;

[7] Ashtanga Hridayam ; Chikitsa sthanam;translated into English by Dr. K.R.Shrikantha murthy, chaukhamba publication, chapter 12; page no 383-390.

[8] Basvarajeeyam; chapter no 9, page no 433.

[9] Bhavprakasha; bhavmishra;chaukhamba publication;Varanasi; volume 2, chapter no 38; page no $484,497,498$.

[10] A text book of kaychikitsa by Dr. P.S. Byadgi and Dr. A. K. Pandey. Volume 2; chaukhamba publication; chapter no 43. page no 684 to 717 .

[11] Cancer, Heart diease and diabetis prevention and its treatment in ayurvedic perspective. Page no 87-93.

[12] Bhaishajya ratnawali by Prof. Siddhinandan Mishra Chaukhamba Sur Bharati Publication 2015, Varanasi, Chapter No.37, Page No.696 to 719.

*Corresponding author.

E-mail address: tushkarnawat90@ gmail.com/ prashant.yavatkar@ gmail.com 